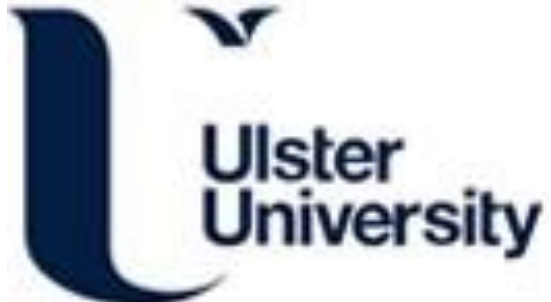

\section{Analysis on field trial of high temperature heat pump integrated with thermal energy storage in domestic retrofit installation}

Shah, N., Wilson, C., Huang, M., \& Hewitt, N. (2018). Analysis on field trial of high temperature heat pump integrated with thermal energy storage in domestic retrofit installation. Applied Thermal Engineering, 143, 650659. [ATE12493]. https://doi.org/10.1016/j.applthermaleng.2018.07.135

Link to publication record in Ulster University Research Portal

\section{Published in:}

Applied Thermal Engineering

Publication Status:

Published (in print/issue): 31/10/2018

DOI:

10.1016/j.applthermaleng.2018.07.135

\section{Document Version}

Author Accepted version

\section{General rights}

Copyright for the publications made accessible via Ulster University's Research Portal is retained by the author(s) and / or other copyright owners and it is a condition of accessing these publications that users recognise and abide by the legal requirements associated with these rights.

\section{Take down policy}

The Research Portal is Ulster University's institutional repository that provides access to Ulster's research outputs. Every effort has been made to ensure that content in the Research Portal does not infringe any person's rights, or applicable UK laws. If you discover content in the Research Portal that you believe breaches copyright or violates any law, please contact pure-support@ulster.ac.uk. 


\section{Abstract}

\section{Keywords}

\section{Highlights}

\title{
Analysis on field trial of high temperature heat pump integrated with thermal energy storage in domestic retrofit installation
}

\author{
Nikhilkumar N. Shah ${ }^{(*) 1}$, Christopher Wilson ${ }^{(*)}$,Ming J. Huang ${ }^{(*)}$, Neil J. Hewitt $^{(*)}$ \\ ${ }^{*}$ Centre for Sustainable Technologies, Ulster University, Newtownabbey, Co. Antrim, \\ BT37 0QB, UK
}

\begin{abstract}
Heat pump and thermal energy storage are important technologies to decarbonise heat and electricity sector. Heat pump integrated with thermal energy storage can provide flexibility to electrical system operator to shift demand to accommodate non-synchronous generators. However, ageing housing stock and high temperature wet radiator central heating system possess some challenges for heat pump installation in the UK. To understand the challenges of retrofit technologies in the domestic sector, a field trial was carried out with a cascade heat pump integrated with a thermal storage tank. The heat pump replaced an existing gas boiler to provide flow temperature of $75^{\circ} \mathrm{C}$ as a retrofit measure without any modification/replacement to existing controller or radiators in the house. The heat pump was integrated with a 6001 thermal store to meet heating demand and system performance was measured in different operation mode such as direct mode, storage mode and combined mode during one-year. The paper provides performance analysis of the system in different mode with operational experience, limitation and issues with the heat pump, house heat loss/insulation and sizing of thermal store in retrofit installation. Additionally, heat pump performance was compared with gas boiler to establish emission and cost saving benefits.
\end{abstract}

Heat pump; thermal energy storage; demand side management; retrofit; field trial, cascade

- Presents 1-year field trial outcome of HTHP and TES in domestic retrofit setting

- Heat pump average COP of 2.2 in direct mode to provide $75^{\circ} \mathrm{C}$ flow temperature

- Storage mode- high energy output during first call for heat but low system COP

- Combined mode-benefits of combined operation of heat pump and TES at peak times

- $\mathrm{CO}_{2}$ emission saving potential of $30 \%$ with COP 2.5 compared to gas boiler

\footnotetext{
${ }^{1}$ Corresponding author: Tel: +44 (0) 2890366122

Email: n.shah@ulster.ac.uk (Dr Nikhilkumar N Shah)
} 


\begin{tabular}{|c|c|c|}
\hline 1 & \multicolumn{2}{|c|}{ Nomenclature } \\
\hline 2 & ASHP & Air-source heat pump \\
\hline 3 & COP & Coefficient of performance \\
\hline 4 & $\mathrm{COP}_{\mathrm{CM}}$ & System performance in combined mode \\
\hline 5 & $\mathrm{COP}_{\mathrm{DM}}$ & System performance in direct mode \\
\hline 6 & $\mathrm{COP}_{\mathrm{SM}}$ & System performance in storage mode \\
\hline 7 & DHW & Domestic hot water \\
\hline 8 & DSM & Demand side management \\
\hline 9 & GSHP & Ground source heat pump \\
\hline 10 & HTHP & High temperature heat pump \\
\hline 11 & PCM & Phase change material \\
\hline 12 & $\mathrm{P}_{\mathrm{E}}$ & Total electrical energy consumption (including fans and pump) (kWh) \\
\hline 13 & PV & Photovoltaics \\
\hline 14 & $\mathrm{Q}_{\mathrm{C}}$ & Heat to storage tank during charging mode by heat pump (kWh) \\
\hline 15 & $\mathrm{Q}_{\mathrm{D}}$ & Heat to house by tank during discharge $(\mathrm{kWh})$ \\
\hline 16 & $\mathrm{Q}_{\mathrm{H}}$ & Heat to house (via central heating) ( $\mathrm{kWh}$ ) \\
\hline 17 & $\mathrm{Q}_{\mathrm{HP}}$ & Heat output by heat pump in direct mode $(\mathrm{kWh})$ \\
\hline 18 & SPF & Seasonal performance factor \\
\hline 19 & $\mathrm{SPF}_{\mathrm{H} 2}$ or $\mathrm{H} 4$ & Seasonal performance factor in heating with boundary condition 2 or 4 \\
\hline 20 & ST & Storage tank \\
\hline 21 & $\mathrm{SH}$ & Space heating \\
\hline 22 & TES & Thermal energy storage \\
\hline
\end{tabular}

\section{Introduction}

UK's clean growth strategy reflects commitment to reduce greenhouse gas by 26 decarbonising heat sector since heat sector accounts for $44 \%$ of total energy consumption [1] 27 and $32 \%$ of total UK emissions [2]. Space heating (SH) and domestic hot water (DHW) 28 consumes $82 \%$ of domestic energy [1], mainly supplied by central heating system (wet radiator system) and present in $90 \%$ of 27.5 million UK's housing stock which is highly dependent on 30 gas as a fuel [3].

Renewables such as photovoltaics (PV), solar thermal and wind have good potential but fails to meet annual domestic energy demand due to intermittent supply in absence of energy storage. Heat pump has shown potential to address the dual challenges of fuel poverty and carbon emission reduction where heat pump market is growing steadily in the UK. However, heat pump installation is still limited in the UK compared to other European countries mainly due to old housing stock, poor insulation, size, lack of policy/grants, building regulations and capital/installation cost etc [4]. This also affects retrofit drives (such as with heat pump) in the 
UK [5]. In addition, most housing stock are fitted with high temperature $\left(60^{\circ} \mathrm{C}+\right)$ hydronic wet radiator system whereas heat pump performance drops at such high flow temperature [6]. There are several investigations on low/medium temperature heat pump application in domestic sector along with storage and renewable technologies which has been reviewed which leads to significance and need of presented work.

\subsection{Literature review}

Heat pumps investigations mainly focuses on two key streams: simulation/modelling and field/experimental trial. For example, Kelly et al. used building simulation model to present benefits and issues on heat pump electrical demand while using storage tank (ST) with phase change material (PCM) or water integrated with heat pump to operate in off-peak periods [7]. Similarly, Arteconi et al. presented TRNSYS model for heat pump with thermal energy storage (TES) to meet domestic heating demand using underfloor heating and low temperature radiators [8]. Heat pump operational benefits with TES has been clearly identified to shift electricity demand during peak time [9] [10]. Kamel et al. provided benefits and limitation through their review that heat pump integration with solar energy requires ST for optimum use and efficiency whereas heat pump integration with PV/T requires optimum control strategy and further study in the area [11]. The impact of PV, electricity pricing and sizing of TES and heat pump is analysed by Fischer et al. [12] The study showed that oversizing of TES can be avoided by overheating of thermal store and rising variability of electricity tariff also increases need for TES. Love et al. presented impact of heat pump electrical load on national grid based on field trial data in the UK. The study presented that the peak demand arises between 6 to 9 am and 4 to $8 \mathrm{pm}$ and $20 \%$ heat pump penetration would not have large enough effect on national grid load profile although this could be mitigated by implementing heat pump control strategies [13].

There are very few example of field trial of heat pump especially in retrofit application. Most heat pump field trial focuses on low temperature and/or underfloor heating system. Safa et al. presented experience of two stage variable speed heat pump and showed $20-40 \%$ higher coefficient of performance (COP) under part load compared to rated capacity for heating and cooling in Canadian climate for domestic building [14]. Kelly and Cockroft presented air source heat pump (ASHP) field trial and simulation model comparison for eight UK houses and showed $12 \%$ less carbon emission compared to condensing gas boiler where ASHP provided $\mathrm{SH}$ via $55^{\circ} \mathrm{C}$ radiator and DHW demand was met by immersion heater [15]. Boait et al. presented case study based on experience of ground source heat pump (GSHP) in retrofit setting for domestic building. They concluded that larger floor area, part load operation (oversized heat pump) and parasitic losses reflects in low COP compared to other European field trials and better controls, design, small houses (new) would help to improve the performance of heat pump [16]. Wu et al. showed benefits of cascade heat pump integrated with TES to reduce pressure ratio at low ambient temperature [17] whereas Shah et al. showed 
1 benefits of engine driven heat pump in off/weak gas/electricity network area to achieve flow temperature in range of $70^{\circ} \mathrm{C}$ with waste heat recovery from the engine [18] [19]. It is also noted that DHW uses 3.5 times more power compared to SH for heat pump where vast installation of heat pump in poorly insulated housing stock could considerably impact peak electricity demand in the UK [20]. On other side, heat pump has potential to promote use of wind-generated electricity and increase wind power capacity utilization to decarbonise electricity in urban areas [21].

In the UK, two major field trials were carried out for heat pumps since 2000 . The first field trial with ASHP and GSHP was carried out by Energy Saving Trust (EST) \& DECC (Department of Energy and Climate Change) in two phases whereas the second field trial was based on the Renewable Heat Premium Payment (RHPP) installations facilitated by DECC. EST's field trial showed that mean seasonal performance factor $\left(\mathrm{SPF}_{4}\right)$ of ASHPs and GSHPs was 2.45 and 2.82 respectively whereas water heating efficiency $\left(\mathrm{SPF}_{\mathrm{H} 2}\right)$ was 2.35 for both type of heat pumps [22]. The second field trial based on RHPP found mean $\mathrm{SPF}_{\mathrm{H} 4}$ of 2.41 and 2.77 for ASHP and GSHP respectively [23]. Both field trials considered flow temperature in a range of 30 to $55^{\circ} \mathrm{C}$, much lower in comparison to retrofit application requirement (above $65^{\circ}$ C). Details about different boundary condition of SPF can be found in [24]. EST's heat pump field trial resulted in a focus on the need for design and installation training. Similarly, Gleeson and Owen et al. highlighted need for proper heat pump installation practice and training which is still lacking in the UK compared to European installation/training practice [25] [26]. Heat pump SPF in German field trial was 2.3 for ASHP and 2.9 GSHP. However, SPF was around 2 at flow temperature near $60^{\circ} \mathrm{C}$ and it was suggested to have SPF above 2.3 to get higher advantage compared to condensing boiler in German market [27]. In the UK, GSHP heat pump trial showed average SPF of 2.38 with further suggestion on monitoring system location and standard practice [28].

\subsection{Proposed work}

The literature review clearly indicates lack of information on high temperature heat pump (HTHP) and TES in domestic retrofit settings. Following points highlights importance and novelty of the proposed work:

- Field trial of HTHP (e.g. $75^{\circ} \mathrm{C}$ ) without replacement of existing radiator/control with minimum intervention as there are no such scientific investigation for domestic sector in the UK.

- Study based on field trial provides deeper understanding for integrated system and issues which may not be identified by simulation as field trial results of UK heat pumps are different than simulated one. It also provides sound basis for further simulation work 
- Investigation for demand side management (DSM) possibilities with heat pump and TES in field trial

The paper describes test set up and compares energy consumption with gas boiler for similar type of house. This would provide good understanding of heat pump and TES operation and benefits to shift electricity for new and retrofit installation.

\section{Details of test house, heat pump and thermal storage system}

\subsection{Test house description}

To understand retrofit challenges two mid-terraced type test houses were used. These were built according to 1900 building standards, typical 'hard to heat' homes (each $96 \mathrm{~m}^{2}$ ). Such type of houses represents about 28\% housing stock in Northern Ireland and UK [3] [29]. Figure 1 shows the purpose-built test houses used in the study and the platform/shed arrangements used for HTHP and TES field trial.
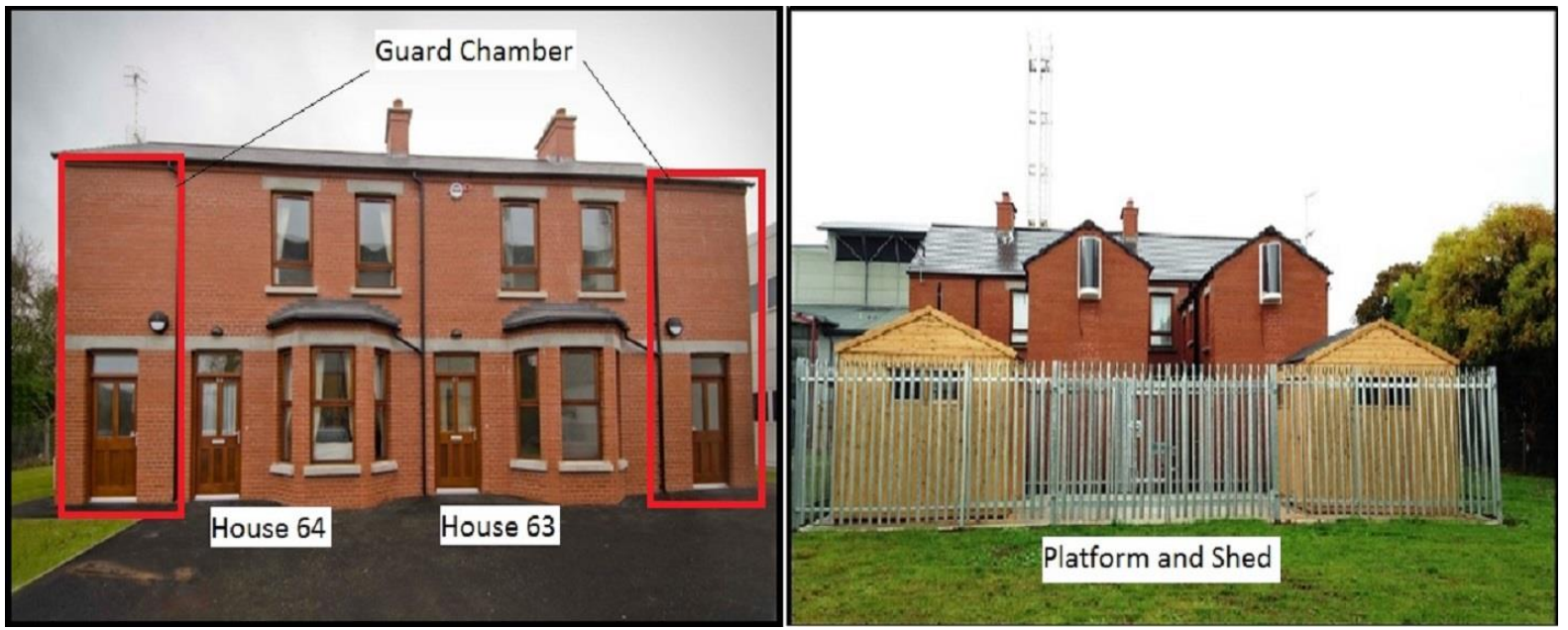

Figure 1 Terraced street test houses at Ulster University

House 63 is occupied by two family members (represents: typical of a working family); whereas House 64 is occupied by three/four adults in a family (represents: University student or person with medical condition or elderly person) who spends more time at home and thus utilises more energy. For this project, house 64 was selected due to a higher energy demand/occupancy. Initially, both houses were equipped with central heating system utilising condensing gas boiler. House 64 was retrofitted with an ASHP and TES where the gas boiler was retained as a backup (in case of heat pump failures or maintenance). House 63 continued to use the gas boiler to provide a comparative analysis for the project.

One of the main objectives of this project was to install a heat pump as a retrofit technology without replacing existing radiators or controls as it saves cost, time and education required for users. In addition, commercially available products were selected to make it a practical solution for field trial as it would be in real world conditions. 


\subsubsection{Heat pump}

Heat pump was sized based on house heat loss and hot water demand calculation. To meet building heat demand at $0^{\circ} \mathrm{C}$ air temperature, an $11-\mathrm{kW}$ heat pump was required. To provide high flow temperature $\left(\left(\right.\right.$ above $\left.65^{\circ} \mathrm{C}\right)$ like gas boiler, commercially available cascade heat pump was selected for this field trial which can provide water temperature up to $80^{\circ} \mathrm{C}$. Outdoor unit used R410A as a refrigerant and uses air as a heat source and provides heat to $\mathrm{R} 134 \mathrm{a}$ based indoor unit. The selected cascade heat pump can provide $11 \mathrm{~kW}$ of heat between $-20^{\circ} \mathrm{C}$ to $16^{\circ} \mathrm{C}$ air temperature with $\mathrm{COP}$ variation from 1.83 to 3.04 at $75^{\circ} \mathrm{C}$ flow temperature as per manufacturer data.

\subsubsection{Thermal storage}

Main objective of TES integration with heat pump was for demand shift by storing heat at night (or at low electricity tariff /high wind penetration) and using stored heat energy to meet part of house heat demand at peak grid electricity demand/price. For this purpose, water was selected as heat storage medium. For the project, a 6001 capacity ST (considering manufacturing limitation and stability) was selected to meet $8 \mathrm{kWh}$ of house heat demand during first hour in the morning. The storage was custom designed to accommodate temperature sensors, immersion heaters and de-stratification pump. The tank was fitted with 2 finned heat exchanger coils each with surface areas of $3.5 \mathrm{~m}^{2}$. The top coil in the tank was used as a discharge coil (to provide heat to house via existing central heating system) and the bottom coil was used as a charging coil (via heat pump).

\subsubsection{Overall test set-up and test methodology}

To achieve purpose of retrofit installation, the heat pump integrated with TES was installed in the shed (temperature maintained around $17^{\circ} \mathrm{C}$ ) behind the house. Figure 2 shows schematics of set-up used for field trial and Figure 3 shows pictures of set-up in field trial.

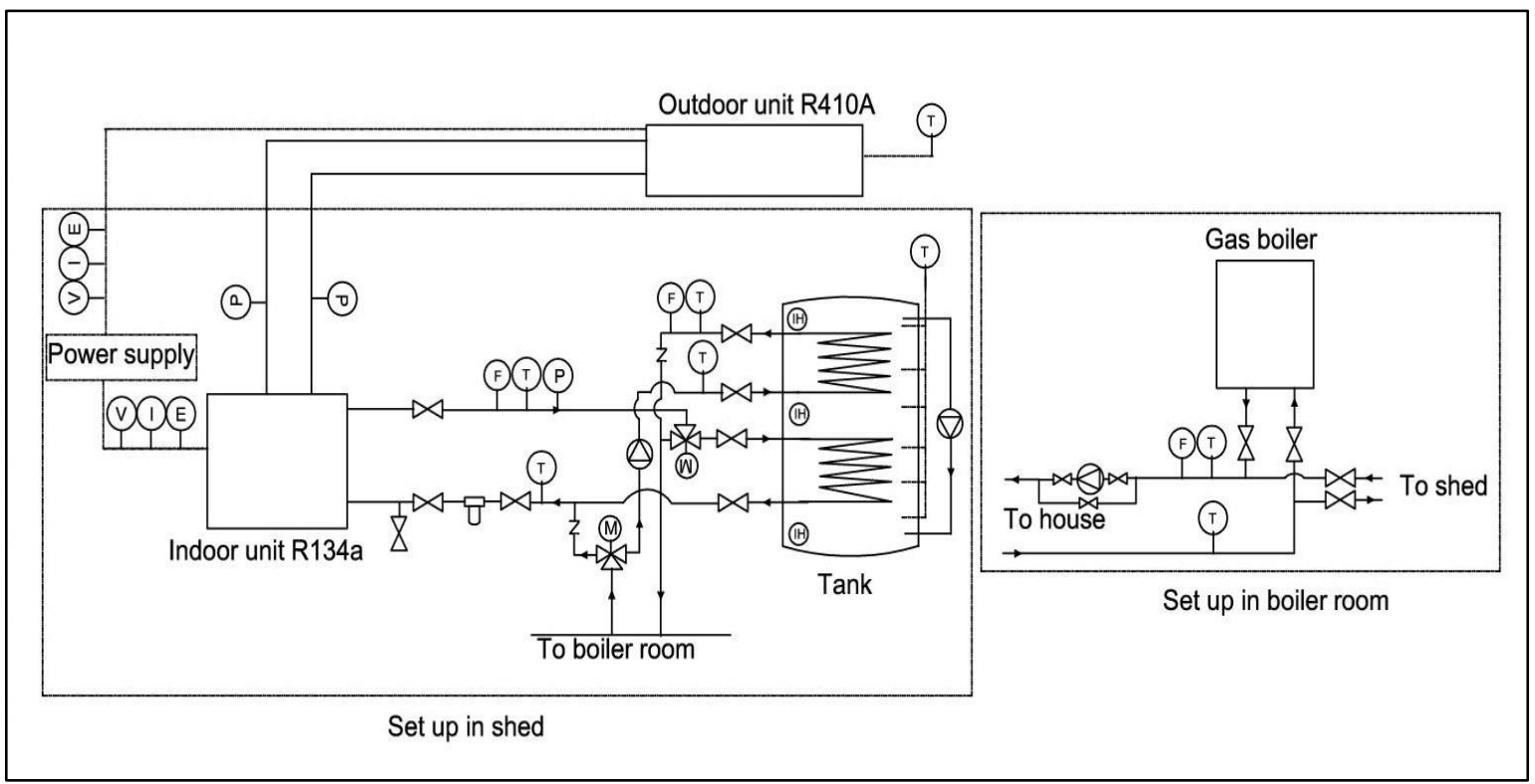




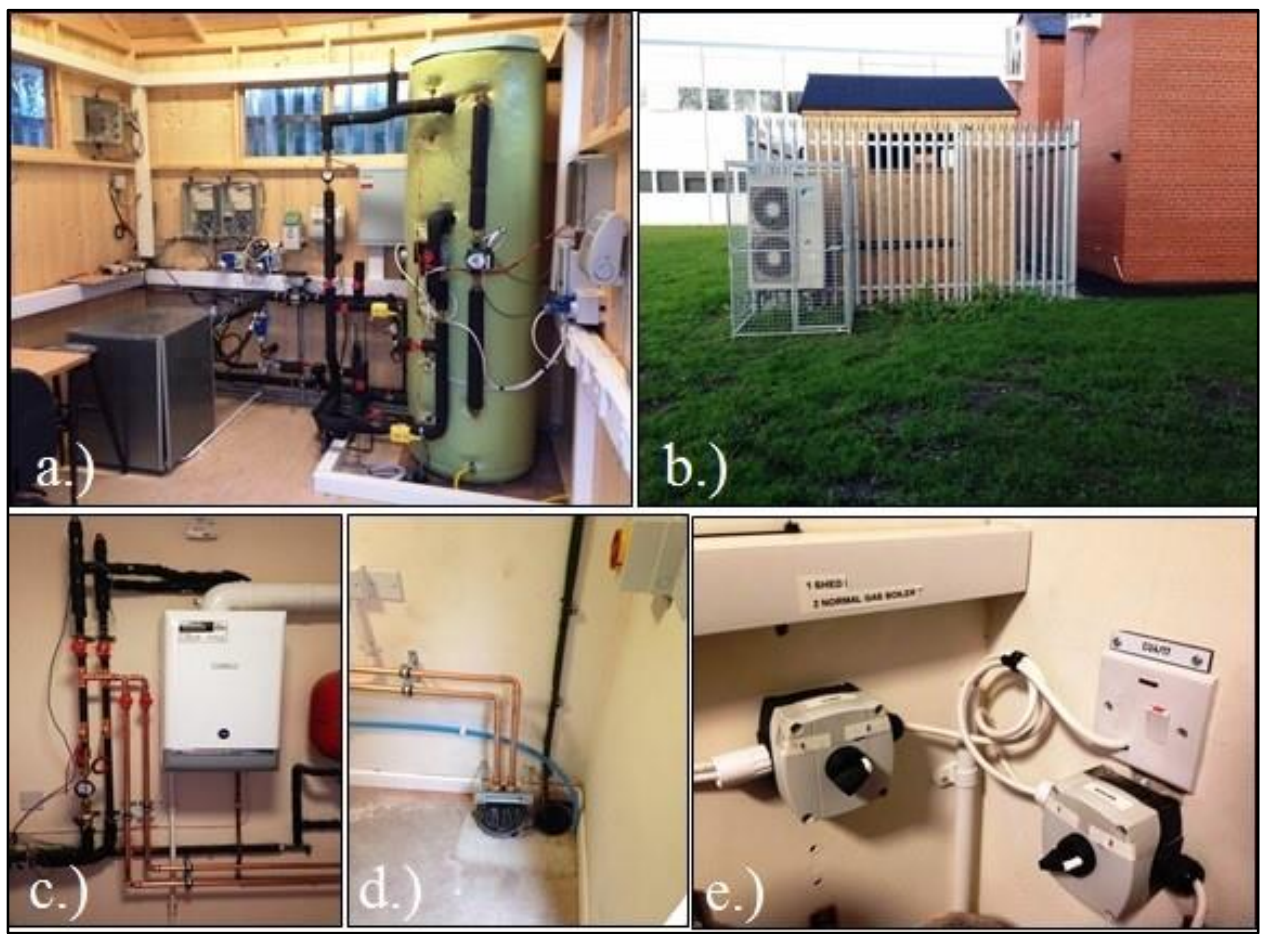

Figure 3 Field trial set-up: a.) Shed: Cascade heat pump indoor unit with R134a \& 600I hot water storage tank, b.) Cascade heat pump outdoor unit with $R 410 A, c, d, e$.) modification in boiler room

In the boiler room, two new pipes, valves and two switches were added to the existing gas boiler set-up. All existing heating controls of gas boiler based central heating system were used for heat pump operation (SH/DHW thermostat, SH/DHW time control). Hence, no intervention was required, and tenants kept using the system as normal. To monitor system performance, the following parameters were logged at intervals of 30s and 60s in two different schedules using a Datataker data acquisition system and stored in a dedicated PC for data analysis purposes:

- Measured parameters: Current, voltage, energy, pressure, water flow rate, water inlet and outlet temperature, air temperature (at outdoor unit) and

- Calculated parameters: heat output/demand, electrical power input and COP

- Accuracy of sensors: Temperature $\left( \pm 0.2^{\circ} \mathrm{C}\right)$, Electromagnetic flow meter $( \pm 1 \%)$, pulse meter $( \pm 1.5 \%)$, Current transducer $( \pm 1 \%)$, voltage transducer $( \pm 0.5 \%)$ and energy meter $( \pm 1.5 \%)$

Prior to commencing the heat pump field trial, gas boiler-based heating system was observed to get estimate of flow and return temperature, energy, time of use etc. More details about initial finding of this field trial were presented by Shah \& Hewitt [30]. Based on those information, heat pump and ST set-point were set. 
1 During the field trial, heat pump and TES was operated in different modes. Figure 4 shows 2 the different mode of operation of HTHP and TES during the 1-year field trial. During direct 3 mode (72 days, starting from November 2014), the heat pump provided heat directly to the 4 house (same as gas boiler). The power consumption of heat pump includes both unit, fans and 5 pump. The performance of the heat pump is representative of $\mathrm{SPF}_{\mathrm{H} 4}$. Daily COP of heat pump 6 in direct mode can be obtained by

$7 \quad C O P_{D M}=\frac{Q_{H}}{P_{E}}$

8 During storage mode (49 days), heat pump maintained constant temperature and stored 9 energy in a tank and ST delivered energy to the house. Daily system performance during 10 storage mode can be obtained by

$11 \quad C O P_{S M}=\frac{Q_{D}}{P_{E}}$

In hybrid/combined mode (244 days), heat pump charged the tank during night time and when there was a call for a heat from the house, the ST discharged and provided heat to the house until the tank temperature dropped to a given set-point (e.g. $55^{\circ} \mathrm{C}$ ). After that heat pump takes over to meet heat demand as in direct mode for rest of the day. During this mode, serval charging and discharging schedules were operated to find optimum timing. Daily performance in combined mode can be given by

$18 \quad C O P_{C M}=\frac{Q_{H}}{P_{E}}=\frac{Q_{H P}+Q_{D}}{P_{E}}$

Energy consumption of House 64 was calculate based on field trial data whereas monthly gas bill was used for House 63 for the same period.
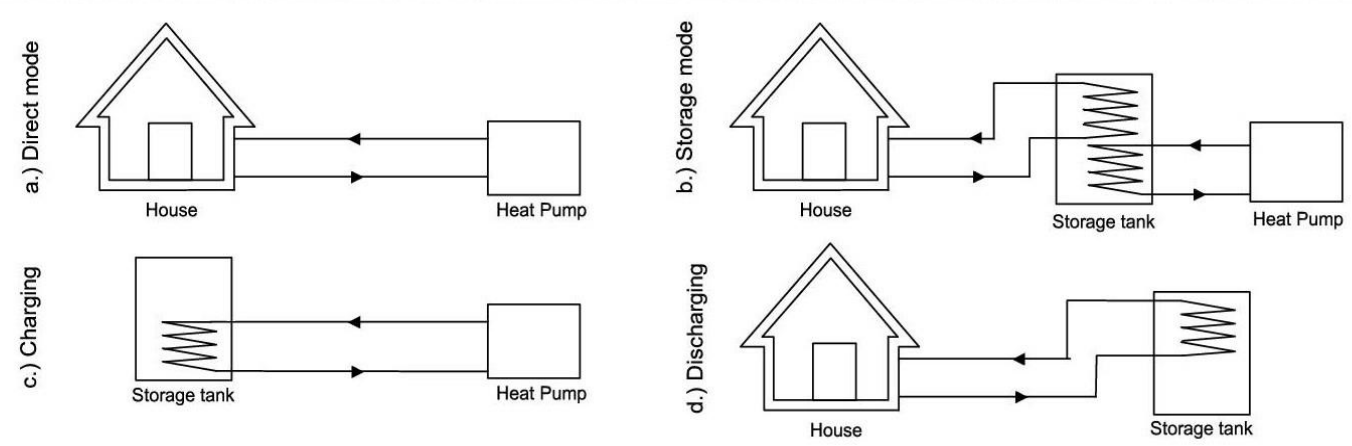

e.) Hybrid (combined) mode $=a+c+d$ 


\section{$1 \quad 3 \quad$ Test results}

Test results have been presented in three sections: First section provides house 64 energy 3 consumption, second section provides HTHP performance with TES in various mode and third 4 section compares energy consumption with house 63(gas boiler) and the case for heat pump 5 for the same period.

\section{$6 \quad 3.1 \quad$ Heat demand variation}

During the field trial, house 64 heat demand varied significantly based on air temperature and occupancy. Figure 5a shows house 64 hourly energy demand variation with room temperature (where thermostat is situated to control $\mathrm{SH}$ ) and air temperature for a day, peak

10 demand occurs in the morning and evening time which is typical of domestic heat demand in 11 the UK.
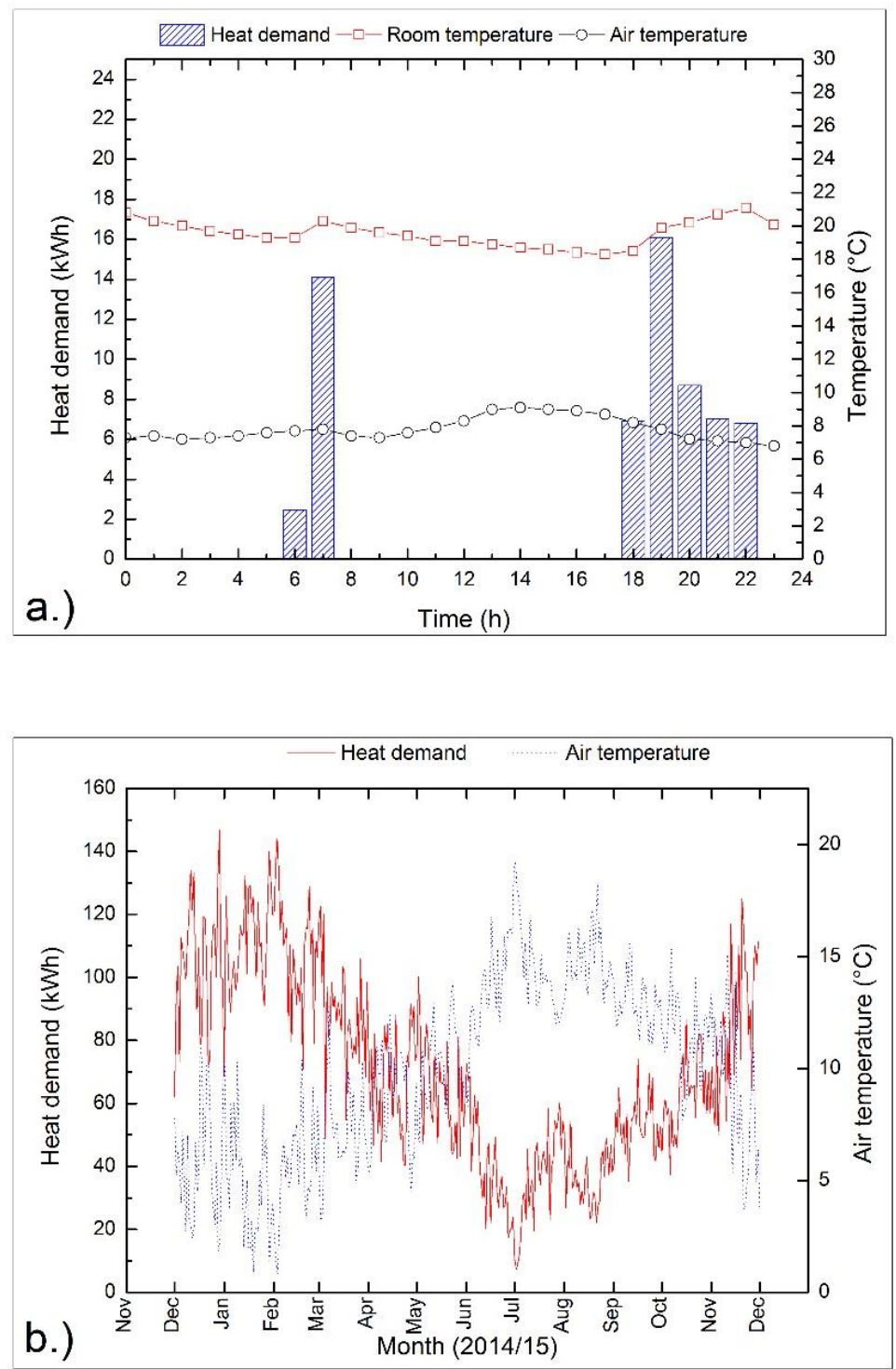
Figure 5 House64 heat demand: a.) hourly heat demand variation, b.) daily heat demand variation (for one year) met by HTHP \& TES

Figure $5 \mathrm{~b}$ shows daily variation of air temperature and heat demand met by HTHP and TES in different operation mode over the year. House 64 annual heat demand was $26014 \mathrm{kWh}$ which is very high and is representative of hard to heat homes. It is evident that $66 \%$ energy demand occurred during November to April. It is worth noting that during the field trial, house SH and DHW demand was exclusively met by heat pump/TES setup and gas boiler and/or immersion heater was not used at all.

\subsection{Heat pump performance in various modes}

During the field trial, HTHP operated in different mode such as direct, storage and hybrid (combined) mode as mentioned earlier.

\subsubsection{Performance in direct mode}

3 Heat pump flow temperature was set at $75^{\circ} \mathrm{C}$ (equivalent to gas boiler) to get performance in retrofit condition. During the first 72 days, performance of HTHP was evaluated in direct mode (first phase) during peak winter season. In addition, 244 days (third phase) heat pump provided heat to house in combined (hybrid) mode where heat demand was met by ST and heat pump directly. Hence, heat provided during direct mode gives total of 316 days of performance data which covers most of the heating season. However, due to corrupted data, seven days data were removed from analysis which gives data analysis of 309 days in direct mode. Figure 6a shows heat pump performance in terms of heat output, electrical power consumption, room temperature and air temperature for a day. There are two peaks of heat demand, typical demand (morning/evening) profile of UK domestic sector. Heat out at starts shows high fluctuation due to large temperature difference between flow and return water.

Heat pump provided $19618 \mathrm{kWh}$ of heat in direct mode in a year with electricity consumption of $9255 \mathrm{kWh}$. Figure $6 \mathrm{~b}$ shows heat pump COP variation in direct mode with air temperature. COP varied between 1.76 to 2.61 during the year with an average COP of 2.2. During field trial, occupants verbal feedback was taken for their thermal comfort and which was confirmed by room temperature measurement too. Heat pump provided heat to house with acceptable thermal comfort to occupants except two days during peak winter season where air temperature was lower than $2^{\circ} \mathrm{C}$. This might have occurred due to simultaneous demand for DHW and heat loss from the house at low air temperature where heat pump ran continuously almost all day to reach desired set point (e.g. $21^{\circ} \mathrm{C}$ ). 

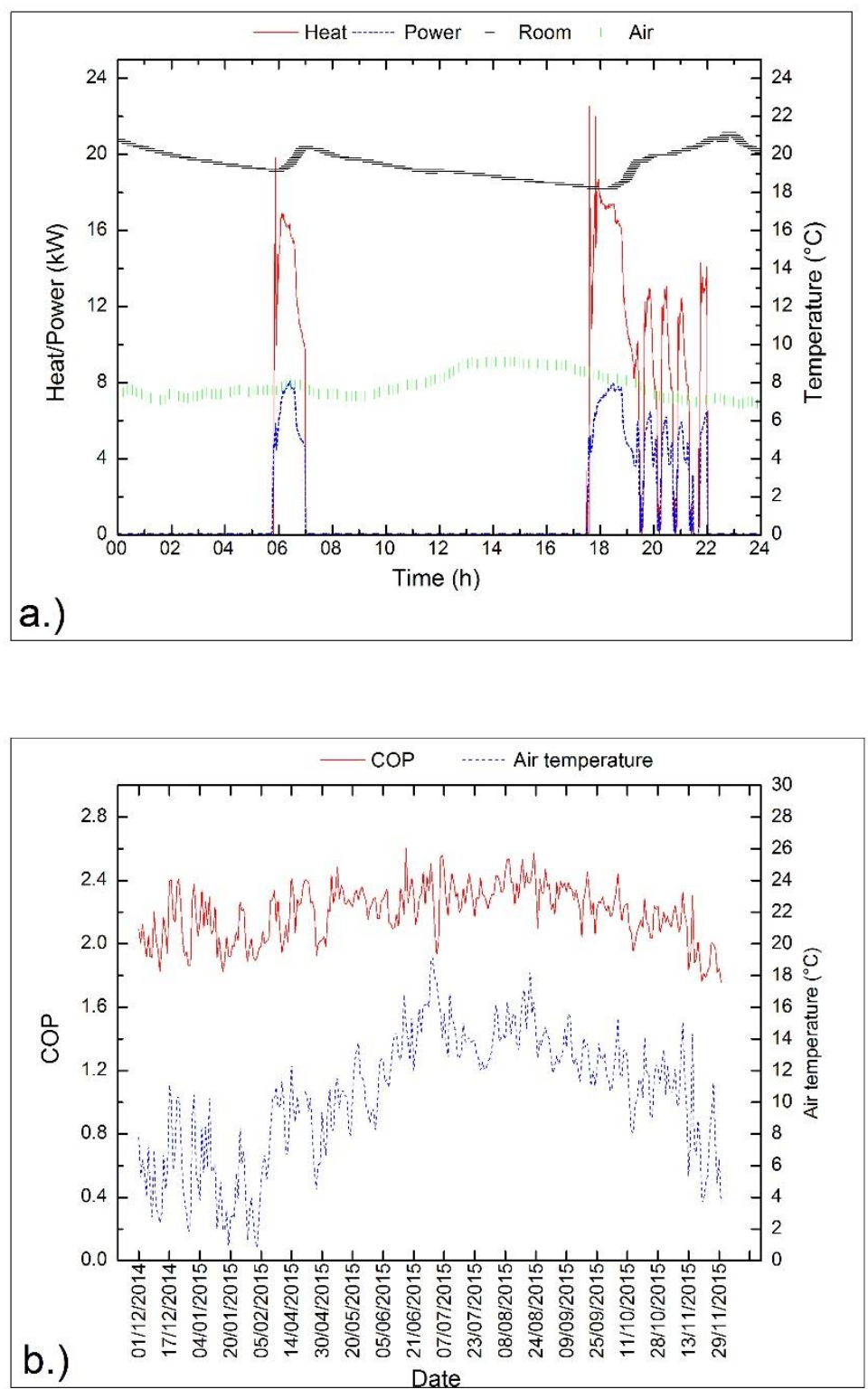

Figure 6 HTHP performance in direct mode: a.) hourly profile of heat output, power, room/air temperature, b.) COP variation during the operation

\subsubsection{Performance in storage mode}

This section is focused on performance of TES, heat pump and interaction with it. Heat pump provided heat to the TES based on night time charging and re-heating functionality of heat pump maintaining a constant temperature (e.g. $75^{\circ} \mathrm{C}$ ) by temperature sensor inserted at the bottom of the tank. Hence, it always sensed low temperature at the bottom of the tank due to stratification compared to the other six temperature sensors above in the tank. Tank discharge was controlled by SH/DHW tank thermostat in central heating system. For example, Figure 7 shows heat pump heat output, electrical power consumption and TES average temperature, heat to house by ST. During this operation heat pump always worked at high flow temperature 
1 (around $80^{\circ} \mathrm{C}$ ) due to high storage temperature and when the storage temperature approaches 2 near $70^{\circ} \mathrm{C}$, heat pump output drops to around $2 \mathrm{~kW}$. Due to high flow temperature conditions 3 heat pump COP drops in storage mode. Hence, storage mode type of operation is not suitable 4 for real house condition due to low efficiency.

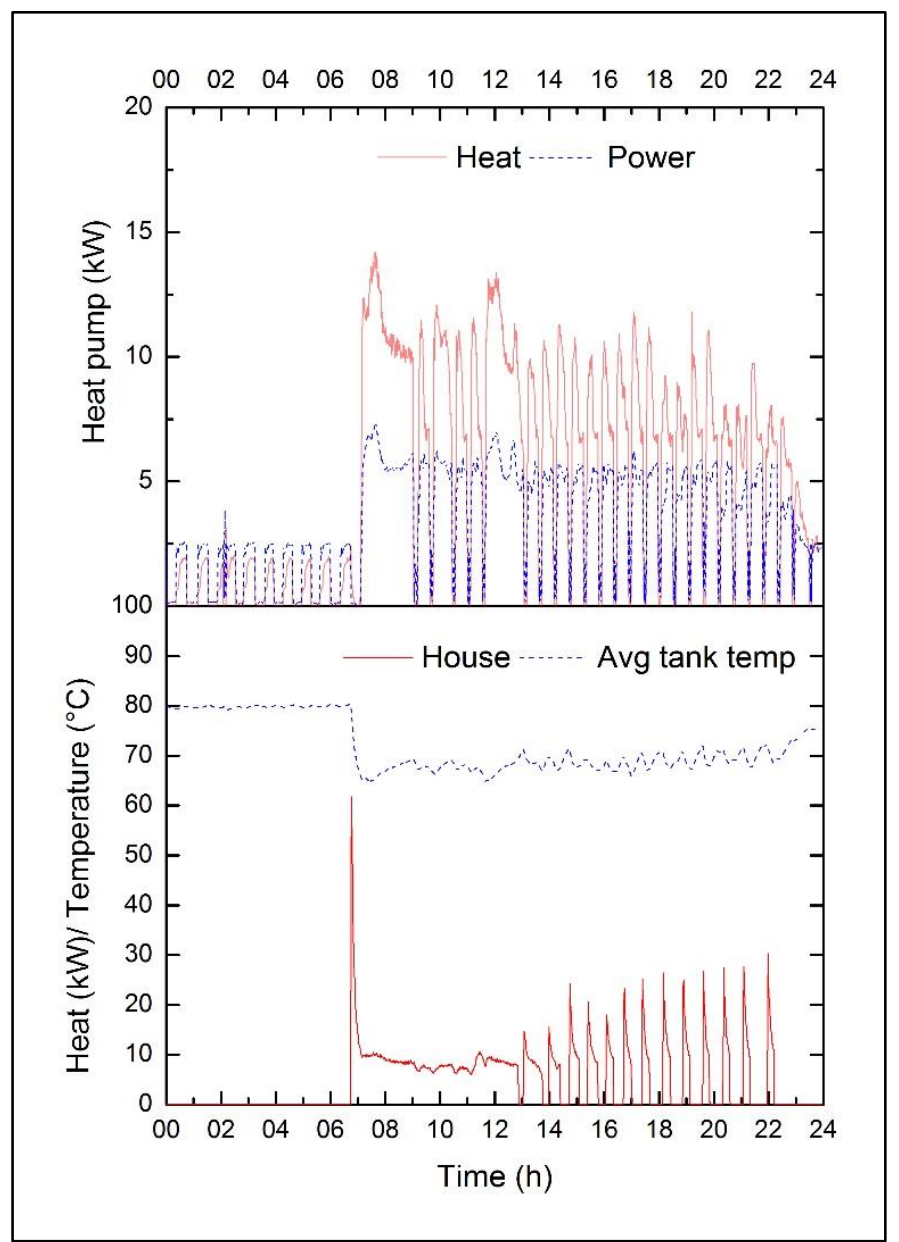

Figure 7 Storage mode performance: heat pump heat and power variation with heat to house and tank temperature

However, during first call for the heat in the morning, TES can provide high heat output due to stored energy which could be helpful for quick heating (e.g. cold days) where heat pump may encounter frequent defrost cycle. Figure 8 shows a sample comparison for five days where heat output after first $30 \mathrm{~min}$ has been compared for first call of the heat in the morning. It is evident that the ST heat output is comparable to gas boiler. De-stat pump on the TES helps to avoid stratification in tank for uniform temperature in the tank but running the pump does not help in delivering more heat. Due to heat loss from the tank, heat by ST to house was less compared to heat by heat pump to ST. Overall storage mode COP was between 1.11 to 1.65 , around $11 \%$ lower compared to net heat pump output to heat pump electrical energy consumption. From this experience, it is worth noting that temperature probe location plays crucial role to store more heat along with good insulation and tank design to improve overall 
1 system performance. Figure 9 shows system performance in terms of COP, heat to ST by heat 2 pump and heat from ST to the house. For data analysis purpose 48 days of storage mode 3 operation data was used.

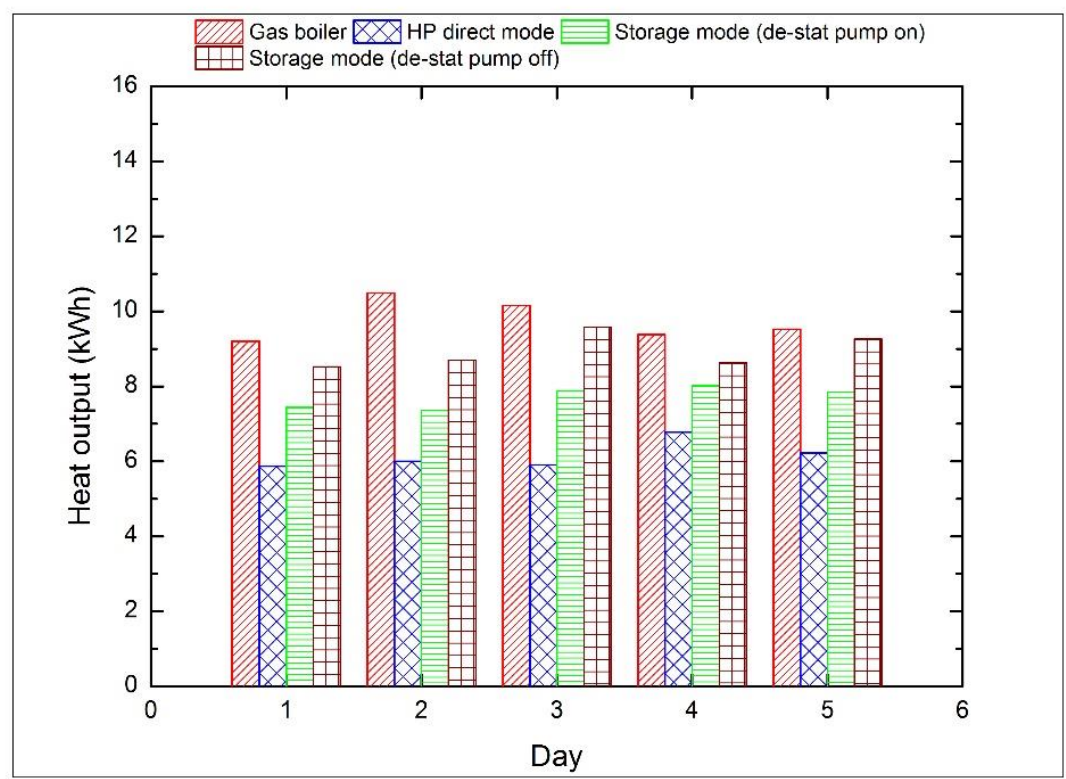

4

Figure 8 Heat output at first call for heat: After 30min

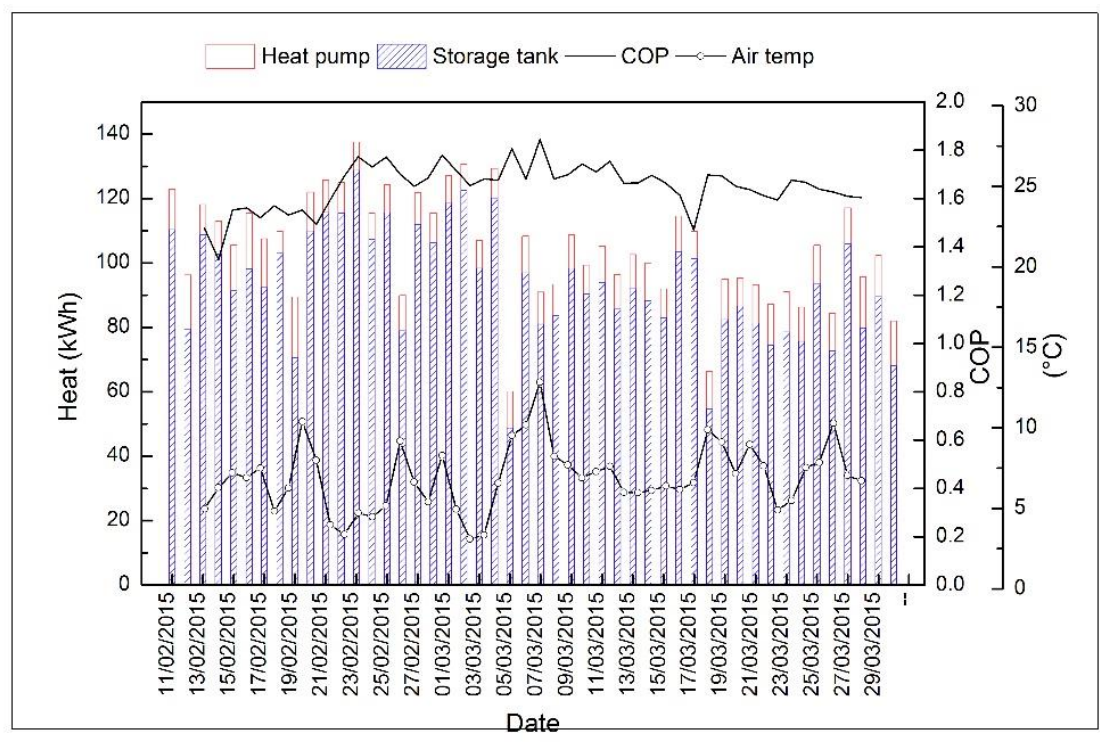

\section{6}

Figure 9 Storage mode: variation in $\mathrm{COP}$, heat output and air temperature

\subsubsection{Performance in combined mode}

Performance of direct mode and storage mode results provided strong basis to study combined effect for optimum performance and flexibility. Figure 10a shows sample of system 
1 operation in combined mode. During night time, heat pump supplies energy to ST and it 2 roughly takes about $1 \mathrm{~h}$ to $2 \mathrm{~h}$ to charge the tank based on temperature set-point (e.g. from $45^{\circ}$ $3 \mathrm{C}$ to $75^{\circ} \mathrm{C}$ ). The first call for the heat from house is met by the ST (half hour to 1 hour) and 4 once temperature drops below set-point, heat pump takes over and provides heat for rest of the 5 day same as in direct mode. Figure 10b shows power consumption of heat pump and ST 6 average temperature variation during that operation. Due to high flow temperature, heat pump 7 power consumption is higher during ST charging than operation in direct mode.
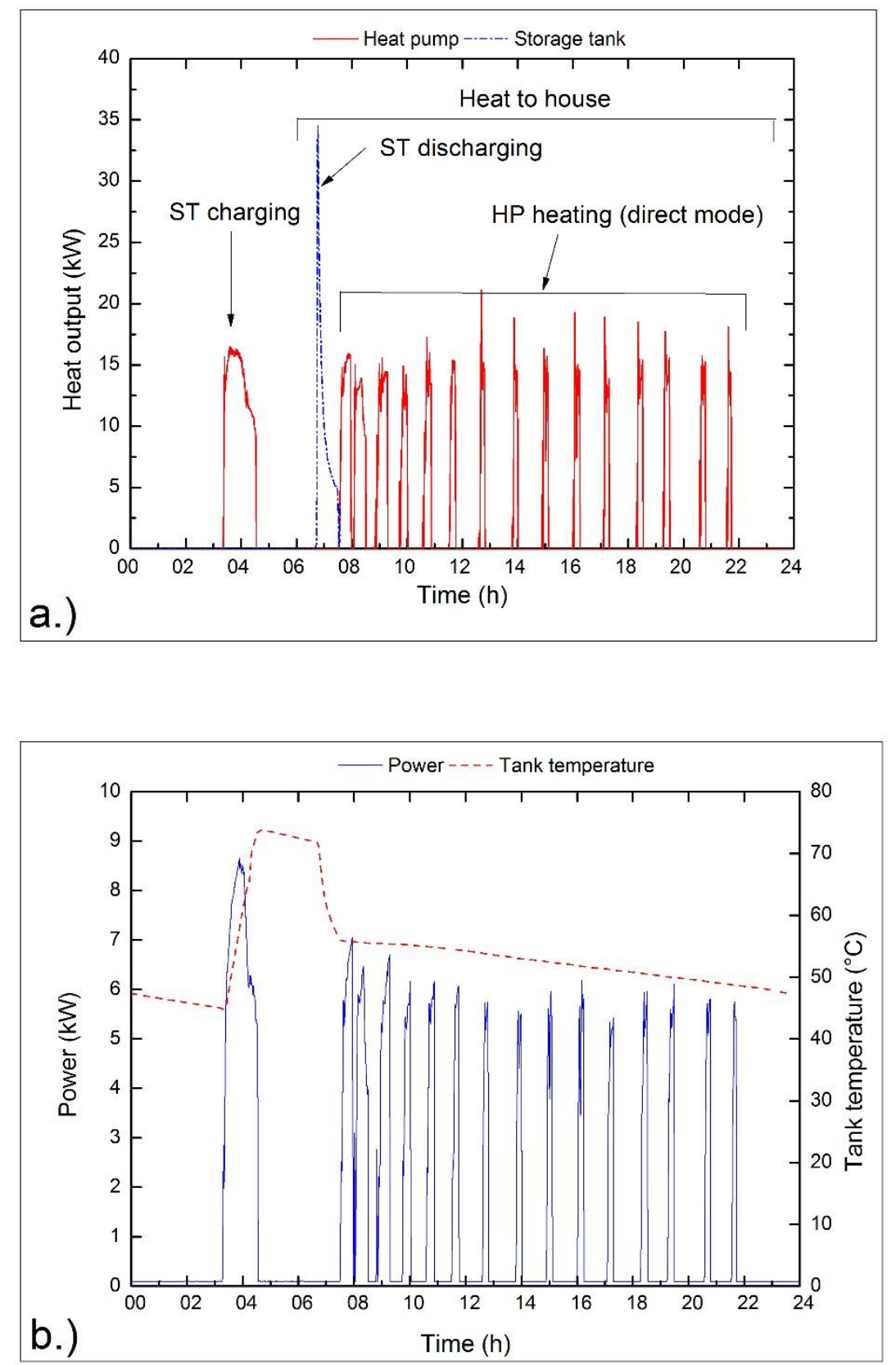

Figure 10 Combined mode operation: a.) heat to house, b.) HTHP electrical power and tank temperature variation 
Figure 11 shows variation of charging, discharging and overall system COP during combined mode. Overall system COP in combined mode varies between 1.7 to 2.43 which is 4 lower compared to direct mode operation mainly due to heat loss from the ST and charging and discharging timing. From system operation experience in three different mode and test result provided good understanding of working of HTHP and TES separately and as a part of integrated system. Further points based on three operation mode and comparison with gas boiler system has been evaluated in discussion section.

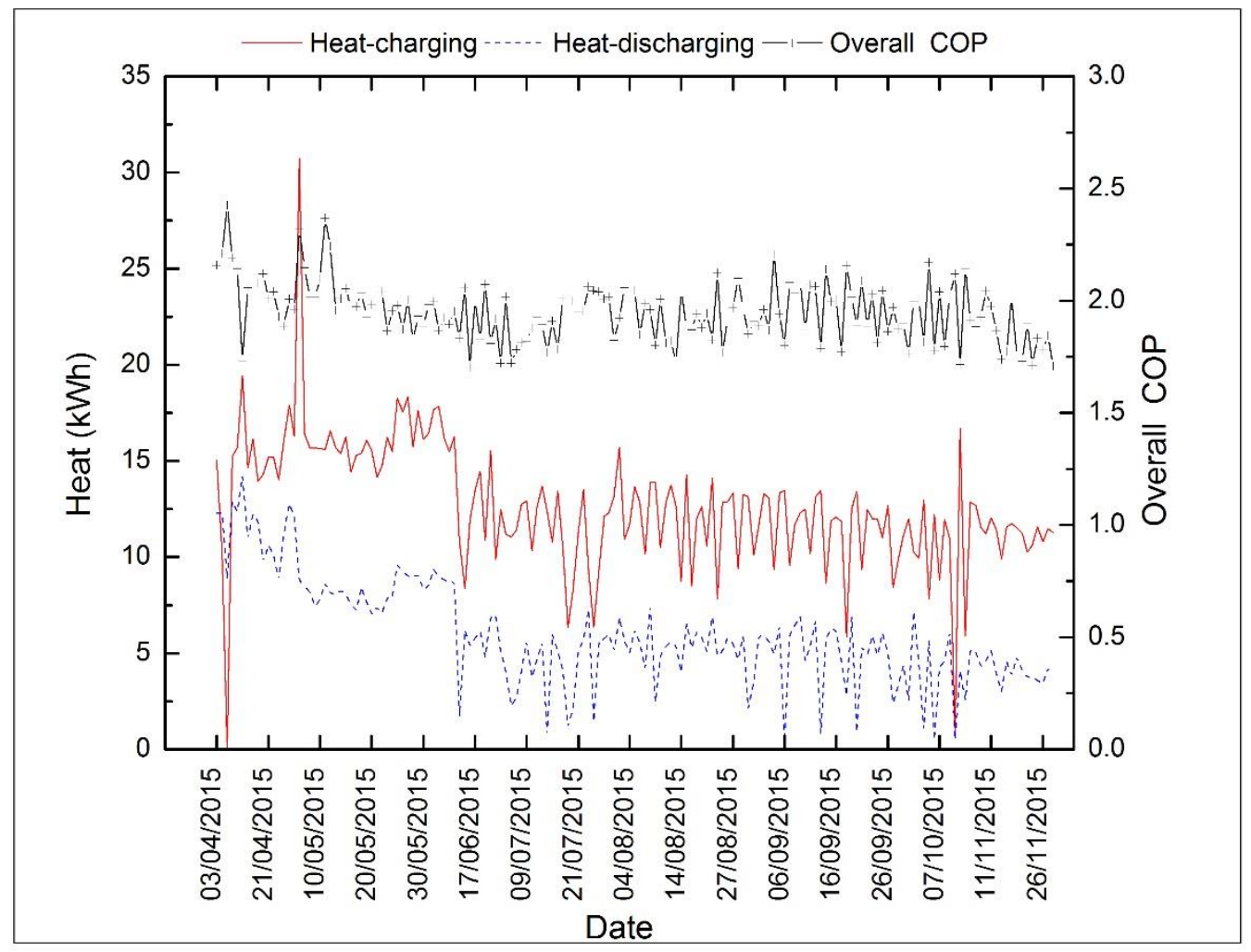

Figure 11 Combined mode: Charging, discharging and overall COP

\section{$11 \quad 3.3 \quad$ Performance comparison}

To compare performance, energy consumption of house 63 (gas boiler) and house 64 (heat pump/thermal storage) were noted for the same period. House 63 energy consumption is

14 calculated using monthly gas bill whereas efficiency of gas boiler was measured (around $80 \%$ ).

15 Figure 12 shows comparison of monthly heat demand for both houses. House 63 annual heating 16 demand was $20043 \mathrm{kWh}$ which is $23 \%$ lower compared to house 64 annual heating demands 17 due to lower occupancy and hence, energy demand. 


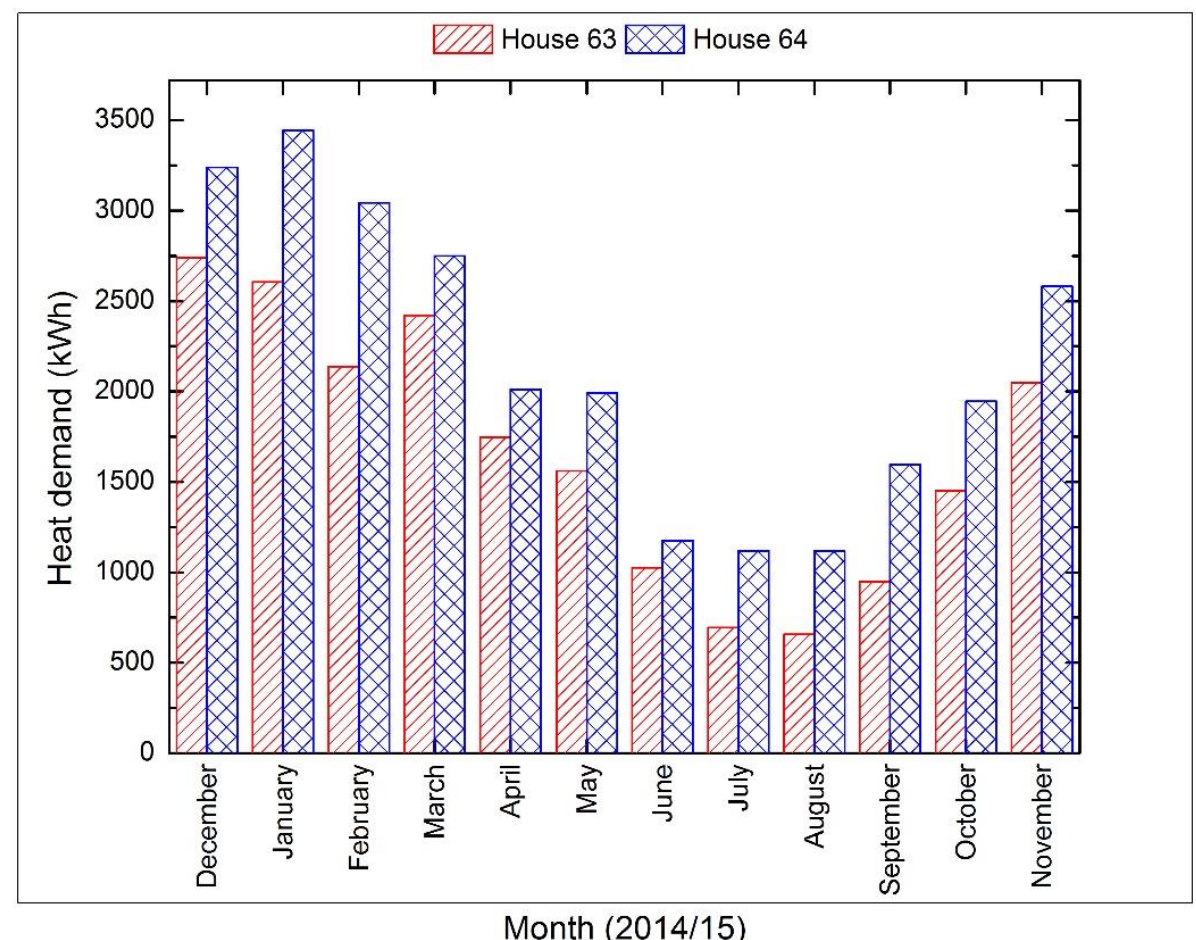

Figure 12 Heat demand comparison based on occupancy/technology

To assess economic viability, heat pump with various COP (annual average) values has been assumed to meet annual heating demand for house 63. To compare $\mathrm{CO}_{2}$ emission, a greenhouse gas factor for natural gas $\left(0.2044 \mathrm{~kg} \mathrm{CO}_{2} / \mathrm{kWh}\right.$ (net CV)) and electricity $(0.4493$ $\mathrm{kg} \mathrm{CO}_{2} / \mathrm{kWh}$ ) (including generation, transmission \& distribution losses) has been obtained from [31].

Table 1 Annual running cost and CO2 emission comparisons between gas boiler and heat pump (house 63)

\begin{tabular}{|l|l|c|c|c|c|}
\hline & & \multirow{3}{*}{ Gas } & \multicolumn{3}{|c|}{ Heat pump } \\
\cline { 4 - 6 } & & & COP 2 & COP 2.5 & COP 3 \\
\hline Annual & Running cost $(£)$ & 1087 & 1413 & 1130 & 942 \\
\hline Cost & Saving (\%) & - & -30 & -4 & 13 \\
\hline \multirow{2}{*}{ Annual $\mathrm{CO}_{2}$ emission } & $\mathrm{CO}_{2}(\mathrm{~kg})$ & 5122 & 4503 & 3602 & 3001 \\
\cline { 2 - 6 } & Saving (\%) & - & 12 & 30 & 41 \\
\hline
\end{tabular}

Table 1 shows annual running cost and $\mathrm{CO}_{2}$ emission comparison between gas boiler and heat pump at different COP. Heat pump with COP 2.5 or more should be able to match running cost of existing gas boiler. With $\mathrm{COP}$ of 2 heat pump provides $12 \% \mathrm{CO}_{2}$ emission 
1 compared to gas. A heat pump with a COP of 2.5 and 3 can save $30 \%$ and $41 \% \mathrm{CO}_{2}$ emission 2 respectively. In addition, renewable heat incentive payment at the rate of $7.63 \mathrm{p} / \mathrm{kWh}$ (on minimum SPF of 2.5) can generate income of $£ 918$ based on existing heating demand. At same rate (and heat demand), it can meet payback period (for heat pump capital \& installation cost) in 7.8 years. This presents good comparison of economic viability of heat pump system.

In addition, heat pump performance with various flow temperature $\left(45\right.$ to $75^{\circ} \mathrm{C}$ ) has been considered to meet heating demand of house 63 for comparative analysis. Heat pump performance at different flow temperature was obtained from manufacturer data. Although actual performance would be lower in domestic installation compared to manufacturer data, but it provides good basis for comparison. Table 2 shows running cost and emission comparison of heat pump at different flow temperature. It is obvious that low flow temperature favours the higher efficiency and hence, low running cost and emission.

Table 2 Heat pump flow temperature impact (house 63)

\begin{tabular}{|l|c|c|c|c|}
\hline & \multicolumn{4}{|c|}{ Heat pump flow temperature $\left({ }^{\circ} \mathrm{C}\right)$} \\
\hline & 75 & 65 & 55 & 45 \\
\hline $\begin{array}{l}\text { Running cost } \\
(£)\end{array}$ & 1089 & 956 & 844 & 813 \\
\hline $\begin{array}{l}\mathrm{CO}_{2} \text { emission } \\
(\mathrm{kg})\end{array}$ & 3471 & 3045 & 2688 & 2590 \\
\hline
\end{tabular}

\section{Discussion}

Field trial of HTHP integrated with TES in domestic retrofit installation highlighted many benefits and issue of such system in different operation. During the field trial, researcher had limited access to house and no influence or intervention on user behaviour or choice of heating demand/control/timing. Additionally, researcher did not change or have access to heat pump controller that manages variable speed, defrost operation etc. Despite the study is limited to one house, its outcome provides valuable information for system integration. First good estimate came from hourly and daily heat demand for the house. High heat demand in house 64 highlights two points: 1.) high heat loss and 2.) occupancy and user behaviour (e.g. more time spent at home with varied thermal comfort requirement such as elderly or person with medical condition). It is crucial to estimate DHW demand as user behaviour remains unpredictable and simultaneous heating, DHW demand and unpredictable user behaviour during cold days pose challenges for heat pump.

Overall heat pump performance was highly influenced by high flow temperature $\left(75^{\circ} \mathrm{C}\right)$ in direct mode and even higher $\left(80^{\circ} \mathrm{C}\right)$ during storage mode operation. In addition, heat pump power consumption also fluctuates based on heating demand with peak power demand of 7.56 $\mathrm{kW}$. Heat pump operation is greatly influenced, not only by air temperature but also by 
1 humidity. It was observed that heat pump operation during low air temperature (e.g. below $2^{\circ}$

2 C or high humidity) was affected by defrost cycle. COP during direct mode was between 1.76

3 to 2.61 which included defrost, pipe losses, fan/pump power and standby power too. This

4 represents about 20\% lower COP compared to manufacture data. Storage mode operation

5 helped to understand simultaneous dynamics of ST charging, discharging with heat pump. High

6 temperature storage doesn't help mainly due to heat loss from the tank and heat pump requires

7 about $5 \mathrm{~K}$ temperature difference to supply heat which increase heat pump flow temperature.

8 Hence, it resulted in low COP between 1.11 to 1.65 in storage mode which includes heat loss

9 from the tank, pipe heat loss, stand by power, HP fan/pump power but excludes ST pump

10 power. However, storage mode helped to deliver large quality of heat during first call for heat

11 which helps to reach room set-point quicker compared to heat pump only operation. Combined

12 mode operation included advantage of both storage mode and direct mode with two focuses for

13 system opration:1.) high heat output during first call for heat in the morning (thermal comfort)

14 and 2.) Displace peak electricity and heat demand (by storage option). Overall system COP

15 remained between 1.7 to 2.43 during combined mode which is lower than direct mode mainly

16 due to lower COP during ST charge operation during night time at high flow temperature and

17 possible low air temperature too.

18 To decarbonise UK's heating sector and to promote decarbonising of electricity (e.g.

19 by avoiding wind curtailment at night-time) sector, heat pump shows promising result to reduce

$20 \mathrm{CO}_{2}$ emission saving. Field trial results showed that heat pump can meet house heating demand

21 with acceptable thermal comfort if its properly size based on occupancy and heat loss. The

22 system operation in storage mode would not be practical solution for domestic building but it

23 can provide some sense for large commercial and industrial application with waste heat

24 recovery option. Heat pump operation in direct mode can be improved further by slightly over

25 sizing heat pump to accommodate unpredictable behaviour of occupant which mainly affects

26 DHW demand. To get optimum benefits and system performance: 1.) charging and discharging

27 time of the tank should be as close as possible to avoid heat loss from the tank, 2.) Possible low

28 storage temperature would help to improve overall COP and reduce heat loss from the tank and

29 3.) DSM strategy and TES size could help electricity network to flatten demand or use excess 30 wind transferring potential benefits to user.

31 Flow temperature of heat pump in retrofit installation plays key role (with conventional 32 radiators) as heat pump with $45^{\circ} \mathrm{C}$ flow temperature can save about $25 \%$ running cost and $\mathrm{CO}_{2}$ 33 emission compared to $75^{\circ} \mathrm{C}$ flow temperature. The test house has nine conventional radiators 34 installed with total heating capacity of $8.5 \mathrm{~kW}$ and it is calculated that if heat pump provides $3545^{\circ} \mathrm{C}$ flow temperature then it would provide about 50\% less heating output [30]. Hence, 36 installing oversized radiators during retrofit installation would cost about $£ 2000$ which could 37 be covered in around 7.5 years. This value is separate from heat pump cost and payback 
1 periods. However, space/orientation rather than cost of radiators is limiting factor in retrofit installations which may still favour HTHP application.

Despite the benefits and potential of such system, large scale deployment of heat pump and TES could be difficult due to available space/size, capital cost and user acceptance. However, advanced small size TES, battery storage and PV system integration could provide solution for system size reduction, performance improvement, smart function and cost benefits.

\section{Conclusion}

Heat pump and TES field trial in domestic retrofit setting showed that the heat pump operation is possible without major modification/replacement of existing heating radiators/controller without compromising on user satisfaction and a need for maintenance. The heat pump achieved an average COP of 2.2 in direct mode despite providing flow temperature at $75^{\circ} \mathrm{C}$. Heat pump operation even with COP of 2 can have $12 \% \mathrm{CO}_{2}$ emission saving and $\mathrm{COP}$ of 2.5 can provide $30 \% \mathrm{CO}_{2}$ emission saving compared to gas boiler with payback period of 7.8 years.

Vast deployment of heat pump integrated TES could be viable and efficient solution if compact TES with possible low storage temperature is used. In addition, integration of electrical energy storage and PV could be beneficial to increase self- consumption and less reliance on grid during peak hours. Smart controller that can work with electricity market signal based on demand, price, weather and tariff could provide flexibility for network operator and user. In addition, potential benefits from DSM could be easily transferred to user for wide scale acceptance of such technology. Large scale installation of integrated technology could provide huge carbon emission and primary energy saving in commercial and industrial sector where simultaneous heating and cooling demand exist with potential of waste heat recovery.

However, for domestic sector, challenges are from design and installation side rather than technology side. Additionally, user perception, lack of awareness and high capital cost is still one of the major reason for not upgrading to innovative technologies. Also, there is no existing policy or market incentives or tariffs for electrical or thermal energy storage which might help to cover the initial cost of the system. In future, more work should carry out to lay down the path for business model and policy frame work which can accommodate and incentivise integrated heating/cooling/electricity generation technologies which can significantly help to reduce to $\mathrm{CO}_{2}$ emission related to heat sector.

\section{Acknowledgement}

33 The authors gratefully acknowledge the support of the European Union INTERREG IVA 34 (Grant number 036347) programme through the Special EU Projects Body (SEUPB) and 35 Engineering and Physical Sciences Research Council (EPSRC) through the Interdisciplinary 36 Centre for Storage, Transformation and Upgrading of Thermal Energy (i-STUTE) (Grant No. 37 EP/K011847/1). 


\section{$1 \quad 7 \quad$ References}

3 [1] DBEIS, "Energy Consumption in the UK," Department for Bussiness, Energy \&

4 Industrial Strategy, London, 2016.

5 [2] HMG, "The Clean Growth Strategy: Leading the way to a low carbon future," HM

6 Government, London, 2017.

7 [3] J. Palmer and I. Cooper, "United Kingdom housing energy fact file," Department of

8 Energy and Climate Change, London, 2013.

9 [4] H. Singh, A. Muetze and P. Eames, "Factors influencing the uptake of heat pump

10 technology by the UK domestic sector," Renewable Energy, vol. 35, no. 4, pp. 873-878,

112010.

12 [5] M. Dowson, A. Poole, D. Harrison and S. Giddeon, "Domestic UK retrofit challenge:

13 Barriers, incentives and current performance leading into the Green Deal," Energy Policy,

14 vol. 50, p. 294-305, 2012.

15 [6] N. Hewitt, M. Huang, M. Anderson and M. Quinn, "Advanced air source heat pumps for

16 UK and European domestic buildings," Applied Thermal Engineering, vol. 31, no. 17-18, p.

$17 \quad 3713-3719,2011$.

18 [7] N. Kelly, P. Tuohy and A. Hawkes, "Performance assessment of tariff-based air source

19 heat pump load shifting in a UK detached dwelling featuring phase change-enhanced

20 buffering," Applied Thermal Engineering, vol. 71, no. 2, p. 809-820, 2014.

21 [8] A. Arteconi, N. Hewitt and F. Polonara, "Domestic demand-side management (DSM):

22 Role of heat pumps and thermal energy storage (TES) systems," Applied Thermal

23 Engineering, vol. 51, no. 1-2, pp. 155-165, 2013.

24 [9] N. Hewitt, "Heat pumps and energy storage - The challenges of implementation,"

25 Applied Energy, vol. 89, no. 1, pp. 37-44, 2012.

26 [10] P. Moreno, C. Sole, A. Castell and L. Cabeza, "The use of phase change materials in 27 domestic heat pump and air-conditioning systems for short term storage: A review,"

28 Renewable and Sustainable Energy Reviews, vol. 39, pp. 1-13, 2014.

29 [11] R. Kamel, A. Fung and P. Dash, "Solar systems and their integration with heat

30 pumps: A review," Energy and Buildings, vol. 87, no. 1, pp. 395-412, 2015.

31 [12] D. Fischer, K. Lindberg, H. Madani and C. Wittwer, "Impact of PV and variable

32 prices on optimal system sizing for heat pumps and thermal storage," Energy and Buildings, 33 vol. 128, no. 15, pp. 723-733, 2016.

34 [13] J. Love, A. Smith, S. Watson, E. Oikonomou, A. Summerfield, C. Gleeson, P. Biddulph, L. Chiu, J. Wingfield, C. Martin, A. Stone and L. R, "The addition of heat pump electricity load profiles to GB electricity demand: Evidence from a heat pump field trial," Applied Energy, vol. 204, pp. 332-342, 2017. 
1 [14] A. Safa, A. Fung and R. Kumar, "Performance of two-stage variable capacity air 2 source heat pump: Field performance results and TRNSYS simulation," Energy and 3 Buildings, vol. 94, pp. 80-90, 2015.

4 [15] N. Kelly and J. Cockroft, "Analysis of retrofit air source heat pump performance:

5 Results from detailed simulations and comparison to field trial data," Energy and Buildings, 6 vol. 43, no. 1, pp. 239-245, 2011.

7 [16] P. Boait, D. Fan and A. Stafford, "Performance and control of domestic ground-

8 source heat pumps in retrofit installations," Energy and Buildings, vol. 43, no. 8, p. 19689 1976, 2011.

10 [17] J. Wu, Z. Yang, Q. Wu and Y. Zhu, "Transient behavior and dynamic performance of 11 cascade heat pump water heater with thermal storage system," Applied Energy, vol. 91, no. 12 1, p. 187-196, 2012.

13 [18] N. Shah, M. Huang and N. Hewitt, "Experimental study of a diesel engine heat pump 14 in heating mode for domestic retrofit application," Applied Thermal Engineering, vol. 98, p. 15 522-531, 2016.

16 [19] N. Shah, M. Huang and N. Hewitt, "Performance analysis of diesel engine heat pump 17 incorporated with heat recovery," Applied Thermal Engineering, vol. 108, p. 181-191, 2016.

18 [20] A. Bagdanavicius and N. Jenkins, "Power requirements of ground source heat pumps 19 in a residential area," Applied Energy, vol. 102, p. 591-600, 2013.

20 [21] M. Waite and V. Modi, "Potential for increased wind-generated electricity utilization 21 using heat pumps in urban areas," Applied Energy, vol. 135, p. 634-642, 2014.

22 [22] P. Dunbabin, H. Charlick and R. Green, "Detailed analysis from the second phase of 23 the Energy Saving Trust's heat pump field trial," 7 August 2013. [Online]. Available: https://www.gov.uk/government/publications/analysis-from-the-first-phase-of-the-energysaving-trust-s-heat-pump-field-trial. [Accessed 106 2016].

[23] R. Lowe, A. Summerfiled, E. Oikonomou, J. Love, P. Biddulph, C. Gleeson, L. Chiu and J. Windfield, "Detailed analysis of data from heat pumps installed via the Renewable 28 Heat Premium Payment Scheme (RHPP)," 2017. [Online]. Available:

29 https://www.gov.uk/government/uploads/system/uploads/attachment_data/file/606818/DEC 30 C_RHPP_161214_Final_Report_v1-13.pdf. [Accessed 2012 2017].

31 [24] A. Riviere, M. Coevoet, C. Tran, A. Zottl and R. Nordman, "D4.2. / D 3.4. Concept for evaluation of SPF," 3108 2011. [Online]. Available:

33 https://ec.europa.eu/energy/intelligent/projects/sites/iee-

34 projects/files/projects/documents/sepemo-

35 build_concept_for_evaluation_of_spf_for_hydronic_hps_en.pdf. [Accessed 0505 2017].

36 [25] C. Gleeson, "Residential heat pump installations: the role of vocational education and 37 training," Building Research \& Information, vol. 44, no. 4, pp. 394-406, 2016. 
1 [26] A. Owen, G. Mitchell and R. Unsworth, "Reducing carbon, tackling fuel poverty:

2 adoption and performance of air-source heat pumps in East Yorkshire, UK," Local

3 Environment, vol. 18, no. 7, pp. 817-833, 2013.

4 [27] K. Huchtemann and D. Muller, "Evaluation of a field test with retrofit heat pumps,"

5 Building and Environment, vol. 53, pp. 100-106, 2012.

6 [28] A. Stafford, "Long-term monitoring and performance of ground source heat pumps,"

$7 \quad$ Building Research \& Information, vol. 39, no. 6, pp. 566-573, 2011.

8 [29] J. Frey, J. Brown, D. McLarnon and S. McCloy, "Northern Ireland Housing Condition

9 Survey," 2011. [Online]. Available:

10 http://www.nihe.gov.uk/northern_ireland_house_condition_survey_main_report_2011.pdf.

11 [Accessed 5 June 2016].

12 [30] N. Shah and N. Hewitt, "High temperature heat pump operational experience as a

13 retrofit technology in domestic sector,"

$14 \mathrm{http} / /$ ieeexplore.ieee.org/stamp/stamp.jsp?tp=\&arnumber=7438691\&isnumber=7438636,

152015.

16 [31] DBEIS, “Greenhouse gas reporting - Conversion factors 2016," Department for

17 Business, Energy \& Industrial Strategy, 1 June 2016. [Online]. Available:

18 https://www.gov.uk/government/publications/greenhouse-gas-reporting-conversion-factors-

19 2016. [Accessed 9 June 2017]. 